\title{
SEED POTATO MINITUBERS PRODUCTION IN A REUSED SUBSTRATE
}

\author{
PRODUÇÃO DE MINITUBÉRCULOS DE BATATA-SEMENTE EM SUBSTRATO \\ REUTILIZADO
}

\author{
Ronei França de ALMEIDA ${ }^{\mathbf{1}}$; Roberta Camargos de OLIVEIRA ${ }^{\mathbf{1}}$; \\ Alexandre Igor de Azevedo PEREIRA ${ }^{2}$; Regina Maria Quintão LANA ${ }^{1}$; \\ José Magno Queiroz LUZ ${ }^{*}$ \\ 1. Institute of Agricultural Sciences, Universidade Federal de Uberlândia-UFU, Uberlândia, MG, Brasil; 2. Instituto Federal de \\ Educação, Ciência e Tecnologia Goiano - Campus Urutaí, Urutaí, GO, Brasil. * jmagno@ufu.br
}

\begin{abstract}
Minituber production is an important step to obtain high-quality seed potatoes. This production is carried out in a greenhouse using a large volume of commercial substrate acquired in specialized trade. An alternative to reduce the volume of substrate purchased for each production of minitubers would be to reuse it, which would be a way to optimize its use. The objective of this study was to evaluate the efficiency of reused substrates in the minituber production. The experiment was conducted in Tapira-MG with the Atlantic potato cultivar. The experimental design was a randomized block with six treatments and four replications, where each plot was represented by a box $(0.15 \times 0.4 \times 0.5 \mathrm{~m}$ : height, width, and length, respectively) containing substrates. Treatments consisted of formulation 04-14-08 rates $\left(0,25,50,75\right.$, and $\left.100 \mathrm{~g} \mathrm{box}^{-1}\right)$ added to reused substrate and a control consisting of a new virgin substrate. At 45 days after transplanting, the following characteristics were evaluated: stem size $(\mathrm{cm})$, and quantities of fresh and dry matter of aerial part of plants. Harvesting was performed manually, counting, and calculating the yield of tubers according to class. The reuse substrate with enriched nutrient regardless of the rate, when compared to the use of a new virgin substrate, did not interfere in potato plant development and in the total productivity of minitubers of classes I, II, III, and IV. This can be a feasible alternative for optimizing the use of the virgin substrate. The rate of $25 \mathrm{~g}$ box $^{-1}$ of 4-14-8 is sufficient to provide the needs of potato in nutrients, ensuring high productivity.
\end{abstract}

KEYWORDS: Plant nutrition. Potato propagation. Solanum tuberosum L. Substrate enriched with nutrients.

\section{INTRODUCTION}

Potato (Solanum tuberosum L.) is the third most important food crop in the world, being the first non-grain commodity and the crop that produces the highest content of nutrients (ZHAO et al., 2016). According to the Brazilian Association of Potatoes (ABBA), potato agribusiness involves around 5,000 producers in 30 regions of seven Brazilian states (MG, SP, PR, RS, SC, GO, and BA) and production varies between 3 million and 3.5 million tons (EMBRAPA, 2016). In 2019 were sold a total of 870 thousand tons of potatoes (CONAB, 2019).

Potato is propagated asexually by "seed tubers", which are the costliest production component. Most of the seed potato seed used in Brazil is imported from other countries, especially the Netherlands (SOUZA et al. 2012). However, the investments in this agricultural input can reduce the production cost and increase the competitiveness against the imported potato seed (CALORI et al., 2017).
Susceptibility to pests and diseases can cause large productivity losses, especially when farmers recycle their own seeds or get them from informal sources (BUCKSETH et al., 2016). Therefore, a high phytosanitary seed is essential for commercial potato production and deserves special producer attention.

In Brazil, propagating material can be obtained in two ways, either imported from several countries such as the Netherlands, Canada, Argentina, and Germany or produced internally via tissue culture (SOUZA et al., 2013). The propagation by shoots of in vitro material is a promising technique in the production of seed potato minitubers since these are free of viruses (SILVA et al., 2006) and it can be a strategy to reduce dependence on imported material and increasing the quality of the national basic seed potato (CAROLI et al., 2017).

Minituber cultivation facilitates the production of seed potatoes and prolongs storage, uses smaller physical space, and shows a longer survival period (WRÓBEL, 2015). Additionally, minitubers can be transported in larger numbers in 
the standard marketing box than larger seed tubers, thereby reducing the cost of transportation (SAMPAIO JÚNIOR et al., 2008).

Minitubers are grown on substrates, which may consist of expanded vermiculite, organic materials (peat, Pinus bark, charcoal rice husk, or organic compost), fertilizers, and additives. A way to reduce the production cost of minitubers and minimize environmental impacts is to reuse the substrates. Thus, reuse allows the reduction of substrate volume discarded after cultivation (FERNANDES; CORÁ; BRAZ, 2006).

The longer the substrate is used, the lower will be the environmental impact due to the disposal of this material (MARIN et al., 2017). However, the substrate's physical, chemical, and biological properties may change with time, which may affect crop development and, consequently, yield (ACUNA et al., 2013).

Chemical fertilizers, usually used in substrates or soils for nutrition supplementation, are recommended for highly responsive crops such as potatoes. However, the use of fertilizers should be oriented according to the stage of crop development and the cultivars' needs (SORATTO, 2011).

Research has reported positive economic responses in consecutive cultivations with different reused substrates, without any decrease in productivity or quality of vegetables (URRESTARAZU et al., 2008). However, there is not enough research evaluating the possibility of substrate reutilization, as well as the concentration of a nutritive solution in this system (MARIN et al., 2017).

Table 1. Chemical composition of the substrates.

\begin{tabular}{cccc}
\hline Soil characteristics & Unit & Virgin substrate & Reused substrate \\
\hline $\mathrm{pH} \mathrm{Ca} \mathrm{Cl} \mathrm{Cl}_{2} 1 \mathrm{M}$ & & 5.6 & 5.5 \\
Total humidity & $\%$ & 53.55 & 50.69 \\
Total N & $\%$ & 0.17 & 0.21 \\
Total organic matter & $\%$ & 29.14 & 28.36 \\
Total organic carbon & $\%$ & 16.19 & 15.76 \\
$\mathrm{P}\left(\mathrm{P}_{2} \mathrm{O}_{5}\right)$ & $\%$ & 0.52 & 0.68 \\
$\mathrm{~K}\left(\mathrm{~K}_{2} \mathrm{O}\right)$ & $\%$ & 0.11 & 0.15 \\
$\mathrm{Ca}$ & $\%$ & 0.54 & 0.67 \\
$\mathrm{Mg}$ & $\%$ & 0.23 & 0.27 \\
$\mathrm{~S}$ & $\%$ & 0.13 & 0.16 \\
$\mathrm{~B}$ & $\mathrm{\% g} \mathrm{kg}$ & 13 & 10 \\
$\mathrm{Cu}$ & $\mathrm{mg} \mathrm{kg}^{-1}$ & 12 & 15 \\
$\mathrm{Fe}$ & $\mathrm{mg} \mathrm{kg}^{-1}$ & 7289 & 8082 \\
$\mathrm{Mn}$ & $\mathrm{mg} \mathrm{kg}^{-1}$ & 116 & 128 \\
$\mathrm{Zn}$ & $\mathrm{mg} \mathrm{kg}^{-1}$ & 100 & 111 \\
$\mathrm{Na}$ & $\mathrm{mg} \mathrm{kg}^{-1}$ & 94 & 150 \\
\hline
\end{tabular}

In order to increase sustainable and conscious management, further studies are required to evaluate the behavior of species and materials that make up the reused substrates and the interaction between them. The objective of this study was to evaluate the efficiency of reused substrates in increasing fertilization rates and to compare these substrates against using only virgin substrate in relation to the production of potato minitubers.

\section{MATERIAL AND METHODS}

The experiment was conducted in an arctype greenhouse with a transparent low-density polyethylene cover and side panels covered with an anti-aphid screen in the city of Tapira-MG, at an altitude of 1340 meters and $19^{\circ} 53$ 'S, $46^{\circ} 40^{\prime} \mathrm{W}$ of geographic coordinates.

The experimental design was a randomized block containing six treatments with four replications, each plot represented by a plastic box with a capacity of $6 \mathrm{~kg}$ of the substrate and $(0.15 \mathrm{x}$ $0.4 \times 0.5 \mathrm{~m}$ : height, width, and length, respectively). The treatments were constituted by five rates of 0414-08 formulation $\left(0,25,50,75\right.$, and $\left.100 \mathrm{~g} \mathrm{box}^{-1}\right)$ added and homogenized to the Bioplant reused substrate and to a control with virgin commercial substrate Bioplant (raw material: fiber and coconut powder aggregates such pine bark, vermiculite, rice husk, and nutrients). In the treatments were added $50 \mathrm{~g} \mathrm{box}^{-1}$ of dolomitic limestone, following the management used by the producer.

The values of the chemical constituents were analyzed according to Embrapa methodology (2017) and are shown in Table 1. 
Seed potato...

The discarded substrate was collected by placing $30 \mathrm{~kg}$ in nylon bags (used for transporting potatoes). Subsequently, the substrate was sterilized by water vapor at $150{ }^{\circ} \mathrm{C}$ for three hours, in a boiler system. After cooling the sterilized substrate was distributed in plastic boxes ( $6 \mathrm{~kg}$ per box).

The steam supplied by the boiler with an evaporation capacity of $30 \mathrm{~kg} \mathrm{~h}^{-1}$ of water, with a pressure up to $7 \mathrm{kgf} \mathrm{cm}^{-2}(100 \mathrm{lbs})$ and a vapor pressure of $1,5 \mathrm{kgf} \mathrm{cm}^{-2}$, which is the force required to overcome the resistance of the substrate mass to the vapor passage.

The water vapor was applied to the center of a cylindrical box with a capacity of 2000 L, containing at the bottom, a layer of $10 \mathrm{~cm}$ of coarse gravel covered by a galvanized screen with a mesh of $2 \mathrm{~mm}$ approximately forming a bottom false. The vapor flows and distributes evenly through the substrate placed inside the carton. For energy saving, the box is externally coated with thermal insulation and capped with plastic film, that can support a temperature of at least $100^{\circ} \mathrm{C}$.

Atlantic cultivar seedlings from the Tissue Culture laboratory located in the city of HolambraSP were obtained by meristem culture and were placed in closed pots containing culture medium. Then, they were transplanted into trays of 128 cells with the substrate (Bioplant ${ }^{\circledR}$ with coconut fiber).

The seedlings transplanted to the trays, called matrices (M), were subjected to an acclimatization process for 7 to 10 days after transplanting. During this period, the matrices were repeated, cutting the caulinar apex leaving at least two leaflets. The cut segment was then induced with an indolebutyric growth regulator to form roots by immersing the fragment into the solution. Subsequently, the matrix peal (RM1) was planted in a tray of 128 cells with the substrate. After one week, RM1 (RR1) was pealed and then was planted in the trays.

Transplanting was carried out on January 2, 2012, with a population of 24 seedlings per box. Irrigation was performed daily using the microsprinkler system according to the plants' needs. Pest and disease control was performed according to the monitoring, and when necessary spraying with products registered for the crop at the dose recommended by the manufacturers.

After 45 days of transplanting, a plant was randomly collected from each plot and sent to the laboratory, where the biological parameters, indicative of plant development, were measured:
ALMEIDA, R F. et al.

stem size, and quantity of fresh and dry matter of aerial part of plants. To measure the size of the stem, a tape measuring in centimeters was used, and an analytical balance was used to quantify the fresh material. The fresh material after being weighed was placed in an oven with forced air circulation at a temperature of $65^{\circ} \mathrm{C}$ and after three days, the total dry matter was obtained.

A sample of the third leaves (leaf + petiole) completely developed from the apex of each plant was sent to the laboratory for quantification of macronutrients (Nitrogen, Phosphorus, Potassium, Calcium, Magnesium, and Sulfur) and micronutrients (Boron, Zinc, Copper, Iron, Manganese), according to the methodology proposed by Embrapa (2017).

The harvest was performed on April 19, 2012, by hand, seven days after desiccation of the plants with Gramoxone (paraquat). The number of tubers in each box was counted and classified as type I (50-60 mm), type II (40-50 mm), type III (30$40 \mathrm{~mm})$ type IV $(23-30 \mathrm{~mm})$, type V $(15-23 \mathrm{~mm})$ and microtubers $(<15 \mathrm{~mm})$.

The results were submitted for analysis of variance by the SISVAR program. The study of the five formulation rates was performed by polynomial regression at $0.05 \%$ of significance. The means of the formulation were contrasted with the control was performed by Dunnett test at the same level of significance $(0.05 \%)$.

\section{RESULTS AND DISCUSSION}

There was no significant difference between the mean values of the virgin and reused substrate plus $25,50,75$, and $100 \mathrm{~g}$ of $04-14-08 \mathrm{box}^{-1}$ for the following variables: stem size, fresh and dry matter of aerial part of plants. Therefore, the addition of nutrients to the substrate reused at 45 days after transplanting (DAT) gave the same vegetative development compared to the virgin substrate (Table 2).

On the other hand, the reused substrate without nutritive complement addition was not effective for plant development (Table 2), which indicates the need for nutrient replacement.

Despite the possible changes in the physical characteristics of the substrate, such as porosity and density, reuse with nutrient addition did not compromise the nutrients utilization by the plants in their vegetative development up to 45 DAT. 
Table 2. Average stems size, fresh and dry matter of potato plants in the function of the virgin substrate and substrate reused combinations with levels of the formula 04-14-08.

\begin{tabular}{|c|c|c|c|c|c|c|c|}
\hline \multirow{3}{*}{ Variables } & \multicolumn{6}{|c|}{ Substrate } & \multirow[b]{3}{*}{ CV $(\%)$} \\
\hline & \multirow{2}{*}{$\begin{array}{c}\text { Virgin } \\
\text { substrate }\end{array}$} & \multicolumn{5}{|c|}{ Reused + 04-14-08 $\left(\mathrm{g} \mathrm{box}^{-1}\right)$} & \\
\hline & & 0 & 25 & 50 & 75 & 100 & \\
\hline $\begin{array}{l}\text { Stem size } \\
(\mathrm{cm})\end{array}$ & 95.25 & $60.75^{*}$ & $77.75^{\mathrm{ns}}$ & $99.75^{\mathrm{ns}}$ & $100.50^{\mathrm{ns}}$ & $97.25^{\mathrm{ns}}$ & 14.04 \\
\hline $\begin{array}{c}\text { Fresh weight } \\
\text { (g) }\end{array}$ & 86.25 & $30.00^{*}$ & $56.25^{\mathrm{ns}}$ & $106.25^{\text {ns }}$ & $98.75^{\mathrm{ns}}$ & $102.50^{\text {ns }}$ & 31.36 \\
\hline $\begin{array}{l}\text { Dry matter } \\
(\mathrm{g})\end{array}$ & 10 & $5.00^{*}$ & $9.75^{\mathrm{ns}}$ & $16.25^{\mathrm{ns}}$ & $16.25^{\mathrm{ns}}$ & $15.50^{\text {ns }}$ & 28.31 \\
\hline
\end{tabular}

*: significant and ${ }^{\mathrm{ns}}$ : not significant by Dunnett test at 0.05 significance.

All the analyzed characteristics obtained a positive quadratic adjustment as a function of 0414-08 doses (Figures 1A, 1B, and 1C). The increased doses are associated with an increase in stem size (1A), fresh matter accumulation (1B), and dry matter (1C), with maximum values of $101.2 \mathrm{~cm}$, $105.4 \mathrm{~g}$, and $16.6 \mathrm{~g}$ at the rates of $77 \mathrm{~g}, 82 \mathrm{~g}, 77 \mathrm{~g}$ 04-14-08 box ${ }^{-1}$ on the reused substrate, respectively. With the dry matter accumulation, fresh matter and stem height were $96.61,92.68$, and $97.13 \%$ as a function of the added rates of 04-14-08 formulation, respectively.

Contrasting results were reported by Favoretto (2005), in which in the Atlantic cultivar, an accumulation of dry matter of $8.65 \mathrm{~g} \mathrm{plant}^{-1}$ and at 53 DAT a stem size of $32.63 \mathrm{~cm}$ were observed. Both responses found were lower than those obtained in the present study.

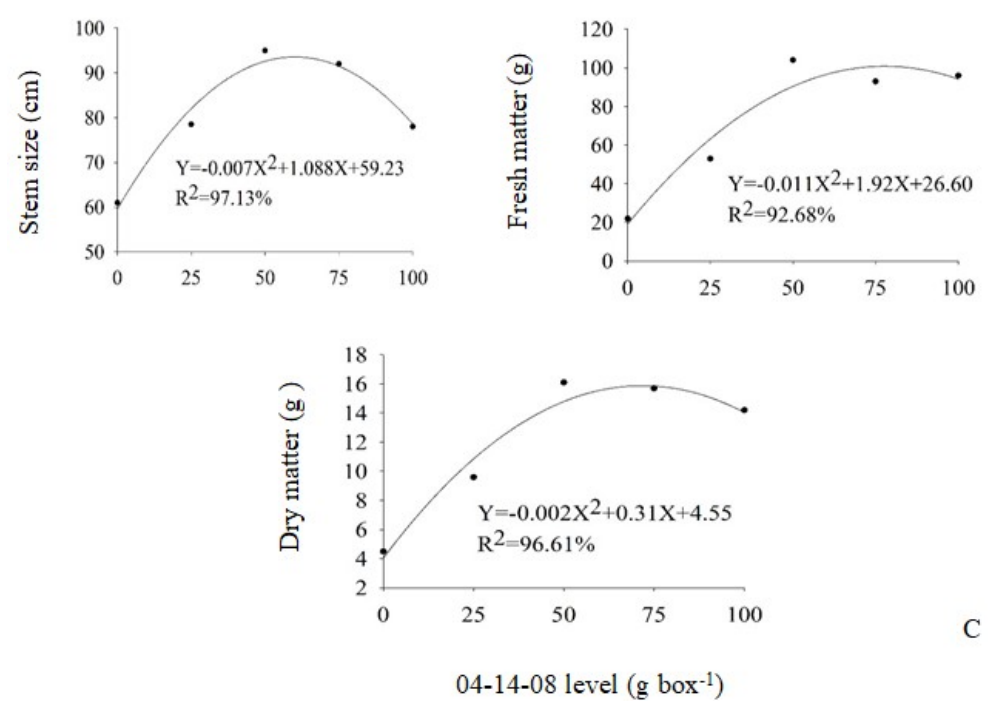

Figure 1. Size stems (A), fresh weight (B), and dry matter (C), the cultivar Atlantic at 45 days after transplanting (DAT) in the function of doses of the formula 04-14-08.

This high level of plant growth in their vegetative development can be justified due to the low light quality that may have occurred in the growing environment (a transparent low-density polyethylene cover) causing the plants to become etiolate. Purquerio and Tivelli (2006) reported that in the protected environment there is a reduction of the solar radiation incidence inside the protected environment in relation to the external environment of 5 to $35 \%$. This reduction may be even greater when there is an increase in the dispersing effect of the plastic or may occur when there is a deposition of dust on the plastic film thus reducing the luminosity inside the structure.

In addition, the plants have different behaviors compared to the time of year when they are cultivated due to the conditions of temperature and photoperiod. In this comparison, the behavior of 
the Atlantic cultivar in relation to the accumulation of dry matter planted was done in January in the present work, and in the work of Favoretto (2005) was done in September.
ALMEIDA, R F. et al.

It was possible to observe that cultivated plants in the virgin substrate presented, in general, nutrient contents within the range recommended by Lorenzi et al. (1996), except for $\mathrm{N}, \mathrm{Ca}, \mathrm{Zn}, \mathrm{Cu}$, and $\mathrm{Fe}$ (Table 3).

Table 3. Average nutrient in potato leaves in relation to appropriate range recommended in the literature and depending on the substrates and the doses of the formula 04-14-08 on 45 DAT.

\begin{tabular}{|c|c|c|c|c|c|c|c|}
\hline \multirow{3}{*}{ Nutrients } & \multirow{3}{*}{ Lorenzi et al. (1996) } & \multicolumn{6}{|c|}{ Substrate } \\
\hline & & \multirow{2}{*}{ Virgin substrate } & \multicolumn{5}{|c|}{ Reused + 04-14-08 $\left(\mathrm{g} \mathrm{box}^{-1}\right)$} \\
\hline & & & 0 & 25 & 50 & 75 & 100 \\
\hline & & \multicolumn{6}{|c|}{$\mathrm{g} \mathrm{kg}^{-1}$} \\
\hline $\mathrm{N}$ & $40-50$ & 31.5 & 14.4 & 16.5 & 44.1 & 24.2 & 22.4 \\
\hline $\mathrm{P}$ & $2.5-5.0$ & 4.5 & 3.3 & 4.5 & 5.5 & 5.5 & 5.4 \\
\hline K & $40-65$ & 46.5 & 50.5 & 58.5 & 57 & 59.5 & 64 \\
\hline $\mathrm{Ca}$ & $10-20$ & 8.4 & 18.3 & 16.3 & 9.6 & 8.2 & 8.5 \\
\hline $\mathrm{Mg}$ & $3-5$ & 3.4 & 3.8 & 3.7 & 3.8 & 3.9 & 3.5 \\
\hline \multirow[t]{2}{*}{$\mathrm{S}$} & $2.5-5.0$ & 3.0 & 3.9 & 3.9 & 3.8 & 4.1 & 2.7 \\
\hline & & \multicolumn{6}{|c|}{$\mathrm{mg} \mathrm{kg}^{-1}$} \\
\hline B & $25-50$ & 41 & 0 & 0 & 0 & 0 & 0 \\
\hline $\mathrm{Zn}$ & $20-60$ & 13 & 41 & 28 & 17 & 15 & 15 \\
\hline $\mathrm{Cu}$ & $7-20$ & 490 & 1583 & 1306 & 735 & 764 & 919 \\
\hline $\mathrm{Fe}$ & $50-100$ & 161 & 693 & 605 & 542 & 550 & 528 \\
\hline $\mathrm{Mn}$ & $30-250$ & 107 & 416 & 236 & 101 & 97 & 107 \\
\hline
\end{tabular}

Similar behavior was observed between the nutrient contents in grown plants on the reused substrate without nutrient addition, or at the lowest applied rate $\left(25 \mathrm{~g} \mathrm{box}^{-1}\right)$, except for $\mathrm{Mn}$ and $\mathrm{B}$.

The water sterilization process carried out on the reused substrate contributed to the increase in the availability of all micronutrients, except B. Silva Júnior et al. (2012) observed higher iron (Fe) and manganese (Mn) contents in sterilized soil compared to non-sterilized soil, which can generate equilibrium between the other ions and change the absorption dynamics.

When the reused substrate was evaluated, the contents of $\mathrm{K}, \mathrm{Mg}$, and $\mathrm{S}$, at all 24-14-08 rates were within the range considered adequate according to Lorenzi et al. (1996). P exceeded the recommended range at doses of 50,75, and $100 \mathrm{~g}$ of 04-14-08 box ${ }^{-1}$. The $\mathrm{N}$ presented values below the minimum threshold at all rates analyzed, except for in $50 \mathrm{~g}$ of 04-14-08 box $^{-1}$.

A reduction in $\mathrm{Ca}$ and $\mathrm{Zn}$ cations contents was observed with an increase in 04-14-08 rates, with rates greater than $25 \mathrm{~g}$ of $04-14-08$ box $^{-1}$ below the appropriate range for potatoes. This imbalance between nutrients may result in lower levels of absorption of some elements and, therefore, lower quality plants (SHAH et al., 2016), which are more sensitive to stressful conditions.

Despite the smaller attraction force by the colloidal fraction of the substrate, the amount of $\mathrm{K}$ present in 04-14-08 formulation can be increased in the retention and in the cation exchange complex by increasing its concentration by displacing cations with a higher ionic radius such as $\mathrm{Ca}$ that can be lost by leaching (MATOS; GARIGLIO; MONACO, 2013). It is necessary to adopt good management with the rate of $\mathrm{K}$ fertilization because the greater solution concentration can reduce the absorption and distribution of the other cations. Marin et al. (2017) also observed this relationship between the cations.

By Dunnett's test at 0.05 significance, there was no significant difference in the total yield of minitubers per box in the treatments with substrate reused, independent of the 04-14-08 rate, in relation to the virgin substrate (Table 4) for type I, II, III and IV. There was a difference for the tubers classified as type $\mathrm{V}$ and microtubers at the doses of $75 \mathrm{~g}$ of 04-14-08 box $^{-1}$ and absence of supplied nutrient, respectively. The reused substrate did not compromise the production and the number of nutrients in the reused and virgin substrate was sufficient to guarantee a good potato development. 
Table 4. Average productivity and classification of potato minitubers as a function of the virgin substrate and reused substrate combinations with the formula levels of 04-14-08.

\begin{tabular}{ccccccc}
\hline & \multicolumn{6}{c}{ Substrate } \\
\hline Variables & Virgin substrate & \multicolumn{5}{c}{ Reused $+04-14-08\left(\mathrm{~g} \mathrm{box}{ }^{-1}\right)$} \\
& & 0 & 25 & 50 & 75 & 100 \\
\hline Total productivity & 27 & $29^{\text {ns }}$ & $30.75^{\text {ns }}$ & $24.25^{\text {ns }}$ & $19.25^{\text {ns }}$ & $20.5^{\text {ns }}$ \\
Type I & 0.25 & $0^{\text {ns }}$ & $0^{\text {ns }}$ & $0^{\text {ns }}$ & $0.25^{\text {ns }}$ & $0^{\text {ns }}$ \\
Type II & 2 & $4.75^{\text {ns }}$ & $5.25^{\text {ns }}$ & $1.5^{\text {ns }}$ & $2.25^{\text {ns }}$ & $2^{\text {ns }}$ \\
Type III & 3.25 & $5.5^{\text {ns }}$ & $7.25^{\text {ns }}$ & $3.75^{\text {ns }}$ & $2^{\text {ns }}$ & $0.75^{\text {ns }}$ \\
Type IV & 3.75 & $9^{\text {ns }}$ & $6.75^{\text {ns }}$ & $3.25^{\text {ns }}$ & $4.25^{\text {ns }}$ & $2.5^{\text {ns }}$ \\
Type V & 6.25 & $7^{\text {ns }}$ & $5.25^{\text {ns }}$ & $3.75^{\text {ns }}$ & $0.75^{*}$ & $3.25^{\text {ns }}$ \\
Microtubers & 11.5 & $2.75^{*}$ & $6.25^{\text {ns }}$ & $12^{\text {ns }}$ & $10.25^{\text {ns }}$ & $12^{\text {ns }}$ \\
\hline$*$ and ns: significant and not significant by Dunnett test at 0.05 significance, respectively. & &
\end{tabular}

Cardoso et al. (2010) observed a decrease in the percentage of aeration space and a consequent increase in water availability to melon plants cultivated in the reused substrate, but like the present study, productivity was not affected by reuse.

Moraes et al. (2016) and Purquerio et al. (2016) also highlighted the advantage of reused coconut substrates over the first-use substrate in the lettuce baby leaf production without any productivity losses.

The average values of productivity varied from 30.45 to 19.25 minitubers per box at the maximum and minimum 04-14-08 rates, which represents 1.27 and 0.80 minitubers per plant, respectively. Grigoriadou and Leventakis (1999) found values of 2.07, 1.85, and 2.52 minitubers per plant for Spunta, Jaerla, and Kennebec potato cultivars. This discrepancy in the values found in the literature with the result obtained may be due to the variation of the reproductive power of each cultivar, climatic conditions, and management, especially because the density of plants per box was high.
In relation to tubers classification (Figure 2), a significant difference was obtained for type III and $\mathrm{V}$ minitubers in relation to the rates, with a maximum value of 6.19 and a minimum of 2.28 minitubers per box at $80 \mathrm{~g} 04-14-08$ box $^{-1}$ and absence of nutrient supplied, respectively. However, the productivity of minitubers type I, II, IV, and microtubers did not differ statistically as a function of the rates of 04-14-08 added in the reused substrate.

According to Figure 2, the increase in 0414-08 doses reflected a reduction in the production of tubers type III and V. For type III, the lowest value was obtained in the highest rate applied, and for type $\mathrm{V}$ there was a reduction until the production minimum at $80 \mathrm{~g}$ of $04-14-08$ box $^{-1}$. The data disagree with Souza et al. (2013) who obtained the largest tubers mass per plant at the highest dose of $\mathrm{N}$ tested but corroborates with Milagres et al. (2013) and Marin et al. (2017) who verified a better effect on productivity under diluted fertilizers in Solanaceae. It can be observed that excessive rates do not necessarily imply an increment in production, which would generate higher costs to the farmer (MARIN et al., 2017).

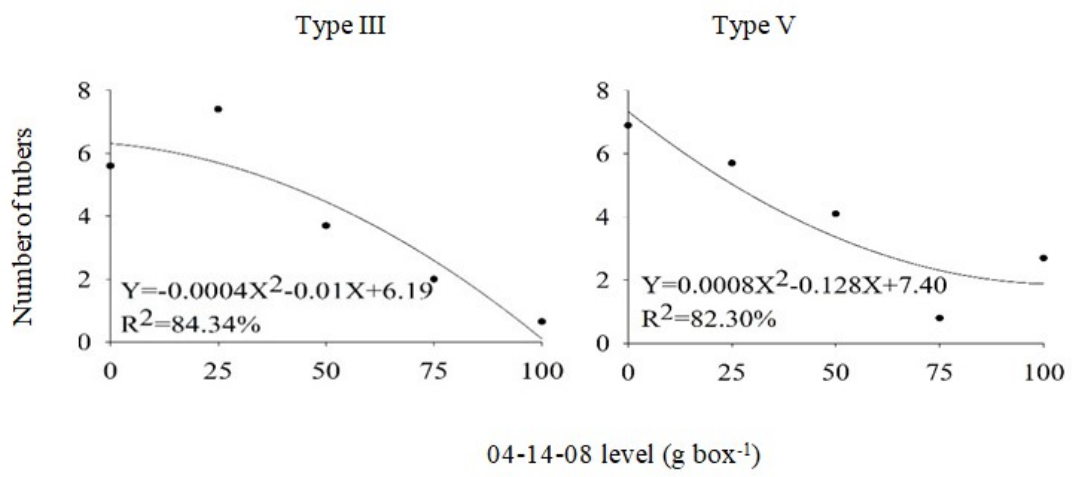

Figure 2. Number of tubers by classification, in the function of 04-14-08 levels. 
The highest minituber value found for type $\mathrm{V}$ classification was 7.4 minitubers per box when the formulate was not added to the reused substrate. Favoretto (2005) found a higher number of cv. Atlantic produced at $70 \mathrm{DAP}$ belonging to type $\mathrm{V}$.

\section{CONCLUSIONS}

Reused substrate enriched with nutrients was efficient in the production of potato minitubers.

Reused substrate with enriched nutrients compared to the use of a virgin substrate did not interfere in potato plant development and total minituber productivity of classes I, II, III, and IV, regardless of the rate.
The dose of $25 \mathrm{~g} \mathrm{box}^{-1}$ of $4-14-8$ is sufficient to provide the nutritional needs of the potato and ensures high productivity.

\section{ACKNOWLEDGMENTS}

The authors would like to thank the funding for the realization of this study provided by Terra Viva Agrícola, the Conselho Nacional de Desenvolvimento Científico e Tecnológico (CNPq), Coordenação de Aperfeiçoamento de Pessoal de Nível Superior (CAPES) and Fundação de Amparo a Pesquisa do Estado de Minas Gerais (FAPEMIG).

RESUMO: A produção de minitubérculos é uma etapa importante para obtenção de batata-semente de alta qualidade. Esta produção é realizada em casa de vegetação e utiliza grande volume de substrato comercial adquirido no comércio especializado. Uma alternativa para diminuir o volume de substrato adquirido a cada produção de minitubérculos seria a reutilização do mesmo, o que seria uma forma de otimizar o seu uso. Neste sentido, objetivou-se avaliar a eficiência de substratos reutilizados na produção de minitubérculos de batata. O experimento foi conduzido no município de Tapira-MG, com a cultivar Atlantic. O delineamento experimental foi o de blocos casualizados com seis tratamentos e quatro repetições, onde cada parcela foi representada por uma caixa $(0,15 \times 0,4 \times 0,5 \mathrm{~m}$ : altura, largura e comprimento, respectivamente) contendo substratos. Os tratamentos foram constituídos por doses do formulado 04-14-08 $\left(0,25,50,75 \mathrm{e} 100 \mathrm{~g}^{\left.\text {caixa }^{-1}\right)}\right.$ adicionadas ao substrato reutilizado e uma testemunha com substrato virgem. Aos 45 dias após o transplantio foram avaliadas as características: tamanho de haste $(\mathrm{cm})$, matéria fresca e matéria seca da parte aérea. A colheita foi realizada manualmente e procedeu a contagem e a produtividade de tubérculos, em classes. O substrato reutilizado enriquecido com nutrientes, independentemente da dose, quando comparado ao substrato virgem, não interferiu no desenvolvimento da planta de batata e na produtividade total dos minitubérculos das classes I, II, III e IV. Esta pode ser uma alternativa viável para otimizar o uso do substrato virgem. A taxa de $25 \mathrm{~g}$ box $^{-1}$ de $4-14-8$ é suficiente para atender às necessidades de batata em nutrientes, garantindo alta produtividade.

PALAVRAS-CHAVE: Nutrição de plantas. Propagação de batata. Solanum tuberosum L. Substrato enriquecido com nutrientes.

\section{REFERENCES}

ACUNA, R. A.; BONACHEL, S.; MAGÁN, J. J.; MARFÀ, O.; HERNÁNDEZ, J. H.; CÁCERES, R. Reuse of Rockwool slabs and perlite grow-bags in a low-cost greenhouse: Substrates' physical properties and crop production. Scientia Horticulturae, v. 160, p. 139-147, 2013. https://doi.org/10.1016/j.scienta.2013.05.031

BUCKSETH, T.; SHARM, A. K.; PANDEY, K. K.; SINGH, B. P.; MUTHURAJ, R. Methods of pre-basic seed potato production with special reference to aeroponics- A review. Scientia Horticulturae, v. 204, p. 79 87, 2016. https://doi.org/10.1016/j.scienta.2016.03.041

CALORI, A. H.; FACTOR, T. L.; FELTRAN, J. C.; WATANABE, E. Y.; MORAES, C. C.; PURQUERIO, L. F. V. Electrical conductivity of the nutrient solution and plant density in aeroponic production of seed potato under tropical conditions (winter/spring). Bragantia, v. 76, n. 1, p. 23-32, 2017. http://dx.doi.org/10.1590/1678-4499.022

CARDOSO, A. F.; CHARLO, H. C. O.; ITO, L. A.; CORÁ, J. E.; BRAZ, L. T. Caracterização física do substrato reutilizado da fibra da casca de coco. Horticultura Brasileira, v. 28, p. 385-392, 2010 
COMPANHIA NACIONAL DE ABASTECIMENTO. Boletim Hortigranjeiro. Brasília. v. 5, n. 2, 2019. 72p.

EMBRAPA- Empresa Brasileira de Pesquisa Agropecuária. Sistema de produção da Batata. 2016. Available from: $<$ https://www.spo.cnptia.embrapa.br/> Accessed in December 222020.

EMBRAPA, Empresa Brasileira de Pesquisa Agropecuária. Manual de Métodos de Análise de Solo. 3 ed. Brasília, (DF): Embrapa, 2017, 577 p.

FAVORETTO P. Parâmetros de crescimento e marcha de absorção de nutrientes na produção de minitubérculos de batata cv. Atlantic. Dissertação (Mestrado em Agronomia)- ESALQ-Escola Superior de Agricultura Luiz de Queiroz, Piracicaba, 2005.

FERNANDES, C.; CORÁ, J. E.; BRAZ, L. T. Alterações nas propriedades físicas de substratos para cultivo de tomate cereja, em função de sua reutilização. Horticultura Brasileira, v. 24, p. 94-98, 2006.

GRIGORIADOU, K.; LEVENTAKIS, N. Large scale commercial production of potato minitubers, using in vitro techniques. Potato Research, v. 42, p. 607-610, 1999.

LORENZI, J. O.; MONTEIRO, D. A.; MIRANDA FILHO, H. S.; RAIJ, B van. Recomendações de adubação e calagem para o estado de São Paulo. Campinas: IAC, p.221-223, 1996. (Boletim Técnico, 100).

MARIN, M. V.; MELO, D. M.; GOMES, R. F.; SILVA, F. M.; CHARLO, H. C. O.; BRAZ, L. T.;

FERNANDES, C. F. Reuse of substrate and nutritive solution concentration on the cultivation of salad tomato. Australian Journal of Crop Science, v. 11, n. 1, p. 102-111, 2017.

http://dx.doi.org/10.21475/ajcs.2017.11.01.287

MATOS, A. T.; GARIGLIO, H. A. A.; MONACO, P. A. V. L. Deslocamento miscível de cátions provenientes da vinhaça em colunas de solo. Revista Brasileira de Engenharia Agrícola e Ambiental, v. 17, n. 7, p. 743749, 2013. http://dx.doi.org/10.1590/S1415-43662013000700008

MILAGRES, C. C.; FONTES, P. C. R.; PUIATTI, M.; SILVA, L. J. Mini-tubérculos de batata semente básica produzidos sob parcelamento e doses de nitrogênio em substrato. Horticultura Brasileira, v. 31, p. 445-449, 2013. http://dx.doi.org/10.1590/S0102-05362013000300016

MORAES, L.A.S.; CALORI, A. H.; FACTOR, T. L.; PATRICIO, F. R. A.; GHINI, R.; ABREU, M. F.; PURQUERIO, L. F. V. Baby leaf lettuce production in trays with reused and solarized substrate. Horticultura Brasileira, v. 34, p. 463-469, 2016. http://dx.doi.org/10.1590/s0102-053620160403

PURQUERIO, L. F. V.; CALORI, A. H.; MORAES, L. A.S.; FACTOR, T. L.; TIVELLI, S. W. Produção de baby leaf em bandejas utilizadas para produção de mudas e em hidroponia NFT. In: NASCIMENTO, WM; PEREIRA, RB (Eds). Produção de mudas de hortaliças. Brasília: Embrapa. p. 221-253, 2016.

PURQUERIO, L. F. V.; TIVELLI, S. W. Manejo do ambiente em cultivo protegido. 2006. Available from: $<\mathrm{http}: / /$ www.iac.sp.gov.br/Tecnologias/MANEJO Cultivo_Protegido/Man.. $>$. Accessed in December 222020.

SAMPAIO JÚNIOR, J. D.; FONTES, P. C.; MOREIRA, M. A.; GUIMARÃES, M. A. Produção de minitubérculo semente de batata, em função de doses de nitrogênio aplicadas ao substrato. Bioscience Journal, v. 24, p. 1- 9, 2008.

SHAH, S. A.; MOHAMMAD, W.; SHAHZADI, S.; ELAHI, R.; ALI, A.; BASIR, A.; HAROON, A. The effect of foliar application of urea, humic acid, and micronutrients on potato crop. Iran Agricultural

Research, v. 35, n. 1, p. 89-94., 2016.

SILVA, E. C.; GIUSTO, A. B.; DIAS, J. A. C. S. Produção de minitubérculos a partir de brotos de cultivares de batata em diferentes combinações de substratos. Horticultura Brasileira, v. 24, p. 241-244, 2006. 
SILVA JÚNIOR, J. M. T.; MENDES, P. F.; GOMES, V. F. F.; GUIMARÃES, F. V. A.; SANTOS, E. M. Efeito da esterilização do substrato sobre o crescimento de mudas de meloeiro em presença de fungos micorrízicos arbusculares e compostos orgânico. Revista Caatinga, v. 25, p. 98-103, 2012.

SORATTO, R. P.; FERNANDES, A. M.; SOUZA-SCHLICK, G. D. Extração e exportação de nutrientes em cultivares de batata: II - micronutrientes. Revista Brasileira de Ciências do Solo, v. 35, p. 2057-2071, 2011.

SOUZA, C. B. S.; FONTES, P. C. R.; MOREIRA, M. A.; PUIATTI, M.; MARTINEZ, H. E. P.; ARAÚJO, R. F. Production of basic potato seed minitubers in substrate and different nitrogen rates. Revista Ceres, v. 59, n. 6, p. 850-858, 2012.

SOUZA, C. B. S.; FONTES, P. C. R.; MOREIRA, M. A.; CECON, P. R.; PUIATTI, M. Produção de minitubérculos de batata semente básica em hidroponia em função de doses de nitrogênio. Revista Ciência Agronômica, v. 44, n. 4, p. 714-723, 2013.

URRESTARAZU, M.; GUILLÉN, C.; MAZUELA, P. C.; CARRASCO, G. Wetting effect on physical properties of new and reused Rockwool and coconut coir waste. Scientia Horticulturae, v. 116, p. 104-108, 2008. https://doi.org/10.1016/j.scienta.2007.10.030

WROBEL, S. Assessment of potato microtuber and in vitro plantlet seed multiplication in field conditions Growth, development, and yield. Field Crops Research, v. 178, p. 26-33, 2015.

https://doi.org/10.1016/j.fcr.2015.03.011

ZHAO, J.; ZHANG, Y.; QIAN, Y.; PAN, Z.; ZHU, Y.; ZHANG, Y.; GUO, J.; XU, L. Coincidence of variation in potato yield and climate in northern China. Science of the Total Environment, v. 573, p. 965-973, 2016. https://doi.org/10.1016/j.scitotenv.2016.08.195 